\title{
Digitaliseringens frontløbere i værdiskabelse: Autentiske aktører og digitale agenter
}

\author{
Af Mogens Kühn Pedersen *)
}

\section{Resumé}

Alle brugere af digitale medier bevæger sig i informationssamfundet, hvor der er nye muligheder og spilleregler for værdiskabelse sammenholdt med de kendte fra den analoge verden. Artiklen belyser:

1) Digitale agenter fremkommet igennem det seneste årti er de nye“ indbyggere” i informationssamfundet. De har ikke direkte reference til autentiske personer. Hvordan kan vi forstå deres betydning for såvel analog som digital kommunikation og sociale relationer? (Afsnit A)

2) Hvilken form for værdiskabelse er knyttet til de digitale agenter og agens? (Afsnit B)

3) Hvilke værdiskabende muligheder og konsekvenser indebærer digital agens: Eksempler (Afsnit C)

4) Hvilke er de socio-økonomiske udviklingsmuligheder med digital agens? (Afsnit D)

5) Hvilke regulatoriske udfordringer stiller de digitale agens til virksomheder og til samfundet? (Afsnit E)

I artiklen behandles disse spørgsmål ud fra samfundsvidenskabelige teorier om digitalisering, værdiskabelse og regulering.

\section{Emneord}

Digitale universer; fællesressourcer; datacyklus; digital personae; digital agens; cookies; API; blockchains; institutionel regulering. 


\section{A. Introduktion}

\section{Kommunikation og sociale relationers digitalisering}

Over ukendte årtusinder har menneskeslægten gradvist forædlet sig som art. Det instinktivt disponerende menneske er stort set fortrængt af kultur-intentionelt, sprogligt avancerede, socioøkonomisk bevidste personer.

Over årtusinder har mennesket udviklet skriftsprog i tillæg til det talte. Skriftsproget materialiserede talesproget og viderudviklede det. Medierne har været ler, sten, træ, papyrus, papir, Gutenberg teknologier, telegraf, telefoni, radiofoni, television, datatransmission, integrerede digitale medier (computere), optoelektronik, mobiltelefoner, smartphones, etc. (Castell 1996)

I nutiden er der skabt en industri, som til stadighed udvikler nye værktøjer til fremstilling af informationssystemer (koder, programmer, applikationer) og til kommunikative fællesskaber (f.eks. Facebook, Twitter), og netværksorganisationer, der driver internetbaseret handel (f.eks. eBay, Amazon) samt sociale produktionsformer i peer-to-peer, open source udviklede systemer med åbne licenser (f.eks. Linux og Apache) (Benkler, 2006, Brynjolfsson \& McAfee, 2014).

Disse eksempler fra en omfattende global udvikling kan sammenfattes under fællesnævneren "information som en ressource". Digitale teknologier anvendes til beherskelse (operationer, kontrol og målbarhed) af data, som kommunikeres og informerer og derved bliver værdiskabende som produkter såvel som i deres anvendelse som services.

Dette adskiller ikke "information som en ressource" fra andre kendte ressourcer så som naturmaterialer og energi. Mennesket behersker i dag to vigtige naturressourcer, nemlig materialer (grundstofferne og deres kombinationer i kompositter, nanoteknologier, m.m.) og hypermobil energi (elektricitet, lagret mobil energi i batterier). Begge er kritiske forudsætninger for udvikling af teknologier til beherskelse af menneskers sprog, skrift og kommunikation og dermed til fortsat at udbygge og forandre menneskers sociale relationer og interaktion (Arthur 2009).

Med digital information er der dannet nye "virkeligheder" af information-energi-materialer, som beherskes af mennesket og ikke af "naturen". Disse virkeligheder er virkelige i deres konsekvenser for de personer, som tager del i dem, en egenskab som først blev påpeget af den polske sociolog Florian Znaniecki i værket om de polske bønder i Polen og USA (i flere bind publiceret 1918-1920) og i hans viderførelse af Durkheim's tanke om sui generis af den sociale orden omend, han tog afstand fra Durkheim's påstand, at den sociale verden kunne studeres med naturvidenskabens metoder og blev i stedet fortaler for en induktiv metode. Den sociale verden er et andet univers end den naturgivne, og den er netop virkelig i sine konsekvenser udtrykt i de sociale handlinger. Sociale relationer kan ikke forstås ved deres naturlige (objekt) egenskaber som sådan. Znaniecki demonstrerede dette i studier af emigrantbreves indflydelse - i hvilke immigranterne overdrev succes og underspillede fiasko - fik indflydelse på de hjemlige polakkers tanker og handlinger om 
at immigrere. Han så kultur som det væsentlige fokus, og definerede kultur som socialt konstruerede relationer. Ved at studere dagbøger, breve m.v. beredte han vejen for den analytiske induktions metodologi på kommunikation. Hans arbejder er også relevante for studier i dag af digital kommunikation og digitale relationer som "culturalism” i et opgør med modstillingen mellem idealisme (subjektivitet) og realisme (objektivitet).

De digitale verdener, vi analyserer her, har egenskaber, som lader sig studere gennem analytisk induktion. Også disse verdener hviler på empiriske observationer af de sociale relationer, som skabes af aktørerne og er forståelige i deres konsekvenser. Denne forståelse blev efterprøvet i et nyere, klassisk studie af operatørers skifte fra fysisk til digital overvågning af maskiner (Zuboff 1988), hvori Zuboff viste, at operatørerne ikke kunne gøre de to verdener, den fysiske og den digitale, kommensurable. Altså at den digitale verden ikke kunne "afspejle" den fysiske for operatørerne. Den digitale verden er ikke et spejl af den analoge.

Forskellen mellem en persons forhold til familiens emigranter i begyndelsen af 1900-tallet og en persons forhold til familiens digitale agenter er netop afstand og kommunikation. I førstnævnte er der absolutte, fysiske barrierer, der ikke kan ophæves; i sidstnævnte er de fysiske barrierer fuldstændigt ophævet og erstattet af de virtuelle, men det er ikke muligt at sidestille den virtuelle verdens digitale agenter med autentiske personer i en operativ, analog sammenhæng, som påvist af Zuboff (1988).

Vi kan konkludere, at sociale relationer i den analoge verden adskiller sig fra sociale relationer i den digitale. Forskellene ligger i den teknologiske omdannelse af kommunikation og interaktion. Det er ikke en 1:1 omdannelse, fordi analoge sociale relationer har et allerede givet tids- og stedspecifikt forhold samt en statusrelation (Kallinikos et al 2010). Disse forhold kan etableres i digital kommunikation, men de er ikke allerede givne lige så lidt, som de er lette at verificere. Synlighed og identitet er heller ikke givet i digitale relationer. De er som oftest givne i de analoge relationer. Således adskiller digitale relationer sig fra analoge på mange områder. Alle har de betydning for social tillid, troværdighed, statusrelationer og dermed for etablering af et følelsesmæssigt tilhørsforhold, som en vigtig betingelse for udvekslinger i personlige forhold. Større økonomiske transaktioner kræver som regel etablering af en grad af forbundenhed baseret på adskillige reelle interaktioner, omend der er kulturforskelle globalt. Hvor en reel social relation med tillid og troværdighed er opbygget, kan den digitale sociale relation videreføre disse, som alle kender det fra familierelationer.

Znaniecki's analyser ledte ham til at afvise opfattelsen af den sociale verden som objektiv, materiel og universel i en naturvidenskabelig forstand. Zuboff (1988) viste, at den digitale verden er væsens forskellig fra den analoge. Turing (1950) - en markant, engelsk datalog (computer scientist) udfordrede computer science til at udvikle den digitale verden til en perfekt illusion af den fysisk- 
biologiske verden således, at den digitale så at sige kunne træde i stedet for den analoge verden. Det betragtede han som et bevis for eksistensen af kunstig intelligens.

I kunstig intelligens (AI) er Turing's "test” det ultimative mål men blandt mange i dag anset for et irrelevant eller misvisende mål, omend ikke komplet uopnåeligt så dog med problematiske følger. Med forbillede i det kendte begreb “værktøj” som står for forlængelse af menneskets egenskaber hurtighed, styrke, præcision, rækkevidde, gentagelse, etc. - bliver de digitale værktøjer set som "muliggørende" eller "støttende" for menneskers erindringer, regnefærdigheder, kommunikation og genanvendelse af data, billeder, stemmer, etc. Alt sammen på en måde, som rummer en digital behandling, som overstiger det enkelte menneskes naturlige evner.

Ud over, at AI kan udvikles som innovativ støtte for en person, så kan andre former for digitalisering bidrage med en ikke mindre væsentlig innovation, nemlig at kunne skabe digital agens, som hverken er alias af personer eller på anden vis repræsenterer personer. Teknologierne (cookies, API og blockchains) blev opfundet i sammenhæng med internettets kommercialisering i 1990'erne og derefter. Agens er "aktører" i den digitale verden. I denne artikel betegner digital agens, eller blot @agens "en virksom eller udløsende faktor” (Den danske Ordbog 2018). Det, som udløses, er kæder af data knyttet sammen af en logik drevet af "autonome" algoritmer, som binder data sammen, og som fordrer forskellig former for governance. Governance står for et system af styring, som omfatter operative regler såvel som mere overordnede principper (Weill \& Ross, 2004). Det har sin oprindelse i opgør med svindel i ledelse af koncerner i USA (Sarbanes-Oxley Act 2002) og har senere fået en pendant i EU såvel som i et nationalt Selskab for god Selskabsledelse (Anbefalinger, April 2010) og i IT governance (Dansk IT 2006, 2011) ${ }^{1}$

I det følgende undersøges den digitalisering, som har egenskaber knyttet til en @agens i relation til materialer, energi, information og - helt afgørende - som sætter mennesker i stand til at styre materialer og energi samt teknologiske elementer, som omfatter "internet of things", hvilket står for aktuatorer og sensorer med kommunikation, der henter data ind over nettet og kan aktivere geografisk, distribuerede computere (Pedersen \& Pedersen 2014). I denne konstruktivistiske forståelse bliver det analytiske fokus flyttet fra et digitalt objekt til mulige, manifesterede konsekvenser af informationsrelationer skabt af @agens.

Ved at udnytte styrbar digital information i det digitale univers har mennesket startet en skabelsesproces for kommunikation, som ikke er et spejlbillede af den sociale kommunikation, men som muliggør nye typer af koordinerede og overvågede dataudvekslinger samt aktiveringer af maskiner med et digitalt interface (Pedersen 1996). Universet af styrbar digital information er genstand for stadige udvidelser, idet de digitale industrier løbende opfinder og designer nye teknologier og "løsninger". Borgere får flere og flere ressourcer til at skabe sig digitale personae, som f.eks. mailadresser, facebook konti, NemID, mens de sociale relationer og interaktioner transformeres til digitale relationer med forskellige værktøjer. Vi står overfor flere interdependente 
teknologiske domæner, som rummer uendelige muligheder for innovationer, jf. data-som-ressource og de innovative materialer i mikroprocessorer samt "motoren" under alt, som er det mobile batteri eller netbaseret vind- og solenergi (Arthur, 2009).

I debatten om kunstig intelligens (AI) er der fokus på forholdet mellem menneske og maskine. Det er den klassiske tilgang, men denne tilgang overser, at den væsentligste udfordring ligger i den digitale agens, som ikke bruges som støtteteknologi til individet men til digitale systemer, altså hvor mennesket ikke er en modsvarigheden til "agens”. Her vil vi beskæftige os med, hvorledes de digitale systemer i egenskab af digitale kan blive nyttige for mennesker på en radikal ny måde, nemlig som systemer, der kan handle autonomt i betydningen selvstændiggjort inden for det digitale univers. Der er ikke tale om automatisering, som er knyttet til et specifikt, velbeskrevet teknologisk objekt i en forudsigelig, programmeret materiel kontekst. Der er tale om en paradigmatisk udvidelse af de menneskelige evner og sanser - alle 7 sanser er nu påvirket af teknologisk udvikling med momenter af "intelligens". "Intelligens" aspektet lader vi ligge, fordi emnet favner meget videre, end hvad vi kan rumme i denne artikel (jf. Dreyfus \& Dreyfus 1986). Vi tager fat om agensproblematikken inden for et digitalt univers. Det er radikalt nyt ved digitalisering.

I det digitale univers sker bruddet mellem "mind \& body" definitivt! Sammenhængen mind \& body er abstrakt til stede i digitale personae, som direkte refererer til et (mind \& body) subjekt eller rettere hævder at gøre det! Den sammenhæng fejler i de mange eksempler på falske personer, som ikke umiddelbart lader sig afsløre som falske. Når en digital personae udskiftes med en digital agens bliver den "digitale personae" med andre ord ikke blot substitueret af den "digitale agens" men tilført helt nye kapabiliteter (jr. Brynjolfsson \& McAfee 2014).

I de digitale universer optræder digitale “agens” med et sæt af tilsigtede “triggers” (igangsættere) implementeret i kæder af data, som til forskel fra tidligere digitalisering, der byggede på klientserver relationer, nu bygger på en datacyklus $i$ et distribueret digitalt univers. Digital agens er helt digital og optræder i en datacyklus, hvilket sker under betegnelserne "cookie”, "API" og "blockchain".

I denne artikel er fokus på springet fra "personae", som den digitale reference til autentiske aktører til den "digitale agens", som er uden reference til aktører men kan have reference til en "personae"type.

Hvordan skal vi forstå forskel på den digitale personae og den digitale agens? Hvilke værdier skaber “digitale agens” for den “digitale personae” og i sidste ende for autentiske aktører?

\section{Formålet med artiklen}

Artiklen vil belyse fremkomsten af tre typer af digital agens: Cookies, api'er og blockchain og undersøge under hvilke omstændigheder, at de kan virke som værdiskabende digitale 
fællesressourcer. Fællesressourcer viser tilbage til Ostrom’s “common pool resources”, som vil blive uddybet i afsnit B.

Den "digitale agens" indebærer en fortsat udvidelse af det digitale univers. Sammenholdt med de forudgående agenter (“digitale personae") udfordrer de nye "digitale agens" kendte normer for ansvar og ansvarliggørelse, som vi kender dem fra personer, såvel analoge som digitale personae. Hvor digitale personae har en fysisk, biologisk modsvarighed, et individ, så har digitale agens ingen sådan modsvarighed.

Artiklen vil udvikle begrebet "digitale fællesressourcer" for at vise nogle nye muligheder med digitale agens. Der er flere vigtige forskelle fra teknologier som f.eks. TV, biler, mobiltelefoner, PC'ere, etc. Det er først de institutionelle forudsætninger, som er radikalt forskellige fra de nævnte eksempler. Endvidere fungerer de tre teknologier kun i en datamodel, som kan beskrives som en triade, hvilket ikke er nødvendigt for ovennævnte for at fungere. En triade involverer 3 autonome enheder, som har relationer indbyrdes (Pedersen 1987). Når triader indlejres i processer, bliver de til datacykler (Pedersen 1996). Når triader indlejres i et digitalt univers, får de nye egenskaber, som beror på digitaliseringens egenskaber.

I cookies og API'ere sker dataudvekslingen i triader på digitale platforme, som er konstrueret af Google, Facebook, Amazon og mange flere. Data sendes fra bruger til platformen og videre til serviceleverandør og tilbage til brugeren.

Sammenkoblingen af triader er det nye ved blockchains sammenholdt med cookies- og apiteknologi. I blockchains (BC) er der forskellige institutionelle konstruktioner til at opbygge en serie af triader. Disse bindes successivt med en irreversibel sammenkobling. Muligheder for at få adgang til en BC reguleres institutionelt. Nogle BC er helt åbne for deltagelse, mens andre stiller specifikke krav til hvem, hvad og hvordan, der deltages.

Vi viser i et eksempel, hvorledes blockchains kan udnyttes til at skabe digitale fællesressourcer, som ikke kan skabes på anden vis.

Disse fællesgoder er ikke kun knyttet til blockchains. Valget af blockchain er et eksempel begrundet i ønsket om at forstå de nye digitale agens, som klart adskiller sig fra digitale agenter, der har "personae" som reference. Forståelsen heraf går fra cookies over API'ere til blockchains.

Alle tre repræsenterer udvikling af digital agens, men det er sidstnævnte, der har særlige institutionelle relationer, som er en afgørende betingelse for deres virke. 


\section{Oversigt over artiklen}

Artiklen præsenterer først værdiskabelse i klassisk økonomi med private goder for dernæst at inddrage en form for goder, betegnet "common pool" ressourcer, som hverken er private eller kollektivgoder i økonomisk forstand, men en ny art økonomisk gode (Ostrom 2010). Et gode som ikke knyttes til den enkelte transaktion men til et institutionelt sæt af betingelser for dannelse af informationsudveksling og handlinger styret af relationer, som har tilsigtede, økonomiske konsekvenser for deltagerne.

Vi betegner disse goder "fællesressourcer" og viser, at under nærmere angivne betingelser kan “digitale løsninger” udvise værdiskabelse ved anvendelse af denne model.

Dette får betydning for forståelse og udvikling af nye former for "digital agens". Disse kan ikke forklares i klassisk markedsøkonomi, hverken som aktører for kollektive goder eller for private goder (Ostrom 2010).

Med eksempler viser vi, hvordan udviklingen af digital agens skrider frem imod større muligheder for at udvikle "digitale fællesressourcer", som påviseligt har stor værdi for deltagerkredsen.

Artiklen afsluttes med en kort diskussion af den samfundsmæssige værdi af mulighederne for at skabe “digitale fællesressourcer"- med referencer til sundhed-, miljø- og klimaproblematikker.

\section{B. Værdiskabende digitale ressourcer}

\section{Et nyt paradigme}

Den nye samfundsvidenskabelig teori om fællesressourcer hidrører fra geografisk spredte studier af naturlige ressourcers administration af Elinor Ostrom og kolleger. Teorien er en sammenfatning af over 40 års studier, som Ostrom gennemførte lige frem til sin død i 2012 kort tid efter modtagelse af "Nobel-prisen" i økonomi i 2009. Fra disse studier kom evidens for et institutionelt paradigme erkendt i slut 80'erne og publiceret sidenhen i flere artikler og bøger (jf. Ostrom 1990). Dette institutionelle paradigme vil vi tage et skridt videre ved at se på dets gyldighedsgrænser. Kan gyldigheden udvides til at omfatte andre ressourcer end de naturlige, knappe ressourcer, som Ostrom studerede? Kan paradigmet anvendes på digitale fællesressourcer?

Først ser vi på nogle egenskaber ved klassisk markedsøkonomi, og hvor den kommer til kort i forhold til digitale goder for derefter at se på digitale fællesressourcer.

\section{Klassisk markedsøkonomisk værdidannelse}

Adam Smith blev ophavsmanden til den markedsbaserede værdiskabelse, mens Hobbes blev ophavsmand til den statslige magtfuldkommenheds styring og indgreb i relationer mellem borgere, herunder også borgere som sælgere og købere på markeder. Det sidstnævnte anså Hobbes som en 
nødvendighed, mens Adam Smith argumenterede for at ophæve "Hobbes nødvendighed af staten". Smith overførte statens magt over markedet til den individuelle, etiske fordring til alle markedsaktører ("moral sentiments") for opretholdelsen af velfungerende markeder, hvilket var til alles fordel, argumenterede han. Dette betød, at "konspiration imod det fælles bedste" (Hobbes anliggende) blev pålagt alle markedsaktører at undlade og derved sikre, at det ikke længere blev et statsanliggende. Men hvordan skulle det sikres, at der ikke blev dannet private fællesskaber? I praksis har det vist sig utilstrækkeligt at påkalde moralske normer, ikke mindst hvis det bliver vanskeligt at afdække identiteten af afvigerne. Incitamentsteori peger på, at der altid er nogen, der lokkes af ekstraordinære (ifølge Smith, umoralske) gevinstmuligheder, såfremt risici for opdagelse og straf kan begrænses. Hvornår er markedets struktur og priskonkurrencen et resultat af aktørernes dygtighed, og hvornår af konspiration i et kartel? Hvis en vare kun kan skabes ved, at en flerhed af aktører koordinerer deres virke, opstår der umiddelbart en markedsforvridning og dermed et grundlag for indgreb i markedet, selv hvis den nye vare fortrænger mindre lødige. Således skabte landmænd i slutningen af 1800-tallet et fællesskab (andelsbevægelsen) for at højne deres produkters kvalitet, hvilket slog igennem på eksportmarkederne og fortrængte mindre lødige landbrugsprodukter. Dette blev dog ikke forhindret af lovgivning eller indgreb her i landet.

Skabelse af private fællesskaber er en udbredt strategi for koncerner, der i stort omfang indgår i vertikal integration gennem opkøb af forbundne virksomheder, hvorved konspirationen imod markedet bliver tilladt. De digitale datakæder virker som drivkræfter til virksomhedsopkøb i mange brancher, hvis konsekvenser ses efterfølgende i form af en større markedskoncentration.

De digitale universer har betydelig indflydelse på brancheopløsning og nye markedsdannelser med stadig større vægt på skabelse af nye digitale ressourcer (Brynjolfsson \& McAfee 2014; Zuboff 2019). I næste afsnit analyseres disse digitale ressourcer.

\section{En digital platform i den markedsøkonomiske værdidannelse}

Under fremvæksten af den digitale økonomi er der ofte henvist til, at værdikæderne blev kortere - i praksis, at producent og kunde rykker tættere til hinanden på bekostning af mellemhandlere som overspringes (Chircu \& Kauffmann 2000; Göersch \& Pedersen 2000; Pedersen 2001). Dette har afgjort fundet sted. Hvad, der også er observeret, er fremvæksten af en ny slags "mellemhandler", nemlig den digitale platform. Tænk på eBay, Amazon og mange flere som platforme, der sammenkobler sælger og køber, hvad angår fysiske varer, men især er blevet vigtige for distribution af digitale produkter og services (Gawer and Cusumano 2002; Evans et al 2006; Zuboff 2015). Gennembruddet for e-handel med digitale programmer kom omkring 2008 med åbning af Apple’s App Store for salg af tredjeparts programmer, betegnet apps. I disse tilfælde ser vi, at den klassiske transaktion bliver erstattet af dataudveksling, som samles i informationskæder med indvirkning på forbrugernes valg af produkt og service. 
Platformens digitale data erstatter det klassiske marked og omfatter data i kontekster af informationsrelationer med mulighed for varierende optimeringer. Realtids-ydelsen er at styre, etablere og moderere leverandør-forbruger relationen med datakæder, som afsætter "fodspor", idet kunden genkendes og historisk datatrafik udnyttes til visning af målrettede tilbud.

Resultatet har været høje årlige vækstrater i e-handel i de industrialiserede lande ledsaget af en gradvis svækkelse af traditionel detailhandel i takt med et øget digitalt udbud og effektive kanaler til distribution. Som følge af opkøb og rationaliseringer er store dele af detailhandlen blevet omdannet til kombinationer af e-handel med pakke-service og strøg-handel i indkøbscentre.

"Mellemhandleren" er en digital agent, som opererer som "platformskonkurrent". Udnyttelsen af positionen har taget en ny drejning efter fremkomst af dele-økonomisk tænkning, der kan realiseres med digitale agenter. Eksempler herpå er Uber og AirBnB, som i begge tilfælde har skabt en "gig økonomi”, hvilket betyder, at den enkelte "operatør" står uden for kendte branchenormer, arbejdsmiljøregler og lønaftaler m.v. Operatøren betragtes som en selvstændig, der stiller sit eget aktiv til rådighed for en marginal betaling for brug (leveret drift eller soveværelse) og uden tillæg for afskrivninger på sit aktiv. Kobling af kunde og leverandør sker over en digital platform, som alene kobler data sammen efter et sæt algoritmer og har som effekt, at en digital servicemulighed skabes, umiddelbart eksekveres og resulterer i en senere afsluttende handling i den reale verden. Platformen er en konstruktion, som fungerer som en udveksling mellem en digital og en real verden under anvendelse af digitale agenter som "trigger" autentiske aktører med reale aktiver (privatbiler, boliger, etc.). Priserne er konkurrencedygtige og servicen er høj for forbrugeren. Platformejeren har begrænset sine markedsrisici ved ikke at investere i aktiver udover selve den digitale platform. Skalerbarheden er høj og adgangen til køb af digital kapacitet som en service medfører, at virksomheden drives med digitale omkostninger, der nøje følger indtjeningen.

Staterne har reageret forskelligt på klager fra taxavirksomheder og hotelkæder, som driver deres forretning ifølge lovgivning og finder konkurrencen urimelig. Nogle platforme har omdefineret tjenesten til "shuttle service" eller indgået aftale om en begrænset regulering, som for eksempel at drive faste ruter og ikke kun gade taxikørsel. Andre steder er der fortsat fri konkurrence.

Således er Smith og Hobbes stadig aktuelle i den digitaliserede økonomi: Stat versus marked, som det kommer til udtryk i myndigheders forskellige reguleringer af nye aktører og markeder.

I det digitale univers er den digitale platform en nødvendig forudsætning for etablering af kontakt mellem udbyder og køber, der er en markedsfunktion, som i økonomisk teori indgår som en transaktionsøkonomisk omkostning (jf. Williamson 1975, 1979), der giver anledning til et institutionelt valg mellem marked og virksomhedsorganisering. Dette valg er ikke til stede i "gigøkonomien”. Platformen - som i eksemplerne Uber og AirBnB - er nødvendig for enhver transaktion. Der er intet alternativ til platformen. Platformen kontrollerer en datakade indlejret i platformen og 
er uden for kontrol af serviceudbyder og køber. Dette er en forskel til transaktioner, som kendetegner det klassiske markeds konkurrence. I fokus er den indlejrede datakæde og aktøren, som kontrollerer datakæden i det digitale univers og kontraktligt kontrollerer dele af de analoge ydelser, men netop ikke står inde for ydelsen i alle dens aspekter. Såvel privatbilens som værelsets tilstand bliver kun angivet i generelle, kortfattede beskrivelser.

Digitale platforme rummer en betingelse, som kan genfindes i Elster's "binding rationality" (jf. Elster 1979), idet både Uber's chauffører og forbrugerne i deres relationer bliver fastholdt af platformen, som "binder" dem sammen i en informationsudveksling, førend der kan etableres en transaktion, her en transportservice i den analoge verden. Vi har med andre ord et skifte fra den industrielle markedsøkonomi i retning af en digitalt, sammenbundet økonomi baseret på "binding rationality", eftersom det er den digitale informationsudveksling, der betinger den økonomiske transaktion, som er indbegrebet af "forretningsmodellen" i platformen. Forretningsmodeller udvikles i platformen som led i udbygning af dens konkurrencemæssige fordele. De kan ligesom andre digitale konstruktioner fortsat udbygges og udvikles (Pedersen 2001; Al-Debei \& Avison, 2010).

\section{Kan platforme skabe "fællesressourcer"?}

Platformen har karakter af et "overvågningskapitalistisk" marked (jf. Zuboff 2015, 2019), hvor der sker en ny form for markedsøkonomisk udvikling, hvor forskellige platforme konkurrerer imod hinanden. Ifølge Zuboff er platformen udtryk for en ny form for kapitalisme.

For at forstå om platforme kan skabe “fællesressourcer” skal vi se nærmere på Ostrom's model. Ostrom's institutionelle paradigme er udviklet i sammenhæng med identifikation af en ny type af økonomiske goder: “Common pool resources” (CPR-goder). Her oversættes CPR-goder til dansk med begrebet follesressourcer, og vi undersøger, hvorvidt det kan udstrækkes til at omfatte digitale fællesressourcer. ${ }^{2}$

Hidtil har vi kendt private goder, klubgoder og kollektive goder. Ostrom lægger vægt på, at CPRgoder er blevet mulige som følge af kommunikation mellem parterne, idet hun påviser, at Hardin's "fælledens tragik" er en model, som baserer sig på fravoer af kommunikation imellem brugerne af fælleden (her: fællesressourcen) (Ostrom 1990). Hardin's tese om de frie fællesressourcers sammenbrud som følge af overforbrug hviler på klassisk økonomisk tænkning om, at enhver kommunikation mellem sælgere indbyrdes eller købere indbyrdes underminerer det frie marked (Hardin 1968). Tragedien refererer til, at den enkelte alene har incitament til at rage til sig uden tanke på andre, så det frie fællesgode forsvinder. Et eksempel ville være ureguleret fiskeri i havene omkring Danmark. Her er der etableret regulering ved EU-direktiver for netop at undgå overfiskning. Ostrom peger på det samme som Elster's "binding rationality”, nemlig at aktører kan indtræde i en forpligtende, kommunikativ relation, som muliggør en bæredygtig udnyttelse af et fællesgode. For Ostrom er den institutionelle governance definerende for etablering af fællesgodet. Ostrom's empiriske studier af cases, hvor et potentielt fællesgode bliver reguleret af de deltagende parter, 
som sikrer godets fortsatte eksistens, har vist, at det er muligt at skabe "common pool resources", der er varige og ikke forbigående. De er hverken kollektive goder eller private goder i den klassiske økonomis forstand, skønt de er set fremstillet som kollektive i deres fremkomst og private i deres forbrug. Forenklingen overser, at det institutionelle paradigmes governance model sammenbinder både adgangs- og forbrugsrettigheder. Derfor er opdelingen af CPR-goder i de to typer af klassiske goder en fortolkning, som tilsidesætter den væsentlige forudsætning for skabelse af godet, det forpligtende, kommunikative fællesskab. Ostrom (2010) understreger, at ændringer i de vilkår, som aktørerne aktuelt er underkastet, ikke med fordel kan overlades til eksterne myndigheder, regeringen, regionen eller kommunen, men bør oendres af aktørerne selv ved at optræde i fællesskab (op.cit. 648). Pointen er en kritik af økonomisk teori, spilteori og "fælledens dilemma" som alle antager, at rammerne for adfærd og for beslutninger er allerede givne og kun mulige at ændre med eksogene kræfter som f.eks. en regering. Ostrom har vist, at der findes utallige situationer, hvor aktørerne med fordel selv kan ændre spillereglerne. Det institutionelle rammeværk omkring skabelse af det kommunikative fællesskab er kort omtalt i fodnote 3 i slutningen af artiklen. De institutionelle reglers fastsættelse og forandring vedrører netop aktørernes ansvar for selv at ændre rammerne for deres fælles virke.

Kommunikation og institutionelle relationer mellem deltagerne har medført, at "fælledens tragedie" er undgået (Ostrom 1990). Kæden af data, som imødekommer kravene i den institutionelle governance, virker vaerdiskabende i sine konsekvenser for hver enkelt deltager i fællesressourcen uden, at den knappe ressource bliver udsat for overforbrug eller underfinansiering.

Hvordan forholder de digitale platforme sig til Ostrom's begreb om fællesressourcer?

I “overvågningsplatformen” er der en central aktør, som suverænt styrer sammenkoblingen af udbyder og køber. For så vidt som at hverken serviceudbyder eller forbruger bliver delagtige i udformningen - hverken direkte eller indirekte - af platformens governance, kan værdiskabelsen ikke betragtes som resultat af et forpligtende, kommunikativt fællesskab. Ingen kommunikation indbyrdes imellem leverandørerne og brugerne bliver understøttet af platformen og må derfor ske med andre midler, om overhovedet. Derfor optræder platformen alene som en mekanisme til skabelse af privatøkonomiske goder for platformsejeren, serviceleverandørerne og brugerne. Forretningsmodellerne danner ikke nogen fællesressource, hverken analogt eller digitalt, men skaber en overvågningskapitalisme (Zuboff 2019), hvor borgernes egne data udnyttes af platformen til værdiskabelsen, som var de frie goder.

Kan der findes andre digitale fællesressourcer? I et studie af opbevaring og adgang til kundskaber har Hess \& Ostrom (2001) set på digitaliserede biblioteker som en fællesressource. Adgang og udbredelse er ikke længere begrænset af formen, som papirbaseret bog eller tidsskrift, hvilket medfører fraværet af en restriktiv knaphed på fysisk tilgængelighed. 
I takt med digitaliseringen af kundskaber bliver fællesressourcens betydning økonomisk reduceret, men den forsvinder ikke, som vi skal se i næste afsnit. Adgang til og udnyttelse af information kræver i sig selv kundskaber og tid, som virker begrænsende på udnyttelsen, skønt informationen er blevet gjort tilgængelig som et fællesgode. I sin analyse af Linux systemet og andre open sourceprogrammer pegede Benkler (2006; 2011) på den globale, distribuerede produktion af fælles værdi i de digitale værktøjer, hvilket kom til udtryk i deres stadig stigende anvendelse på alverdens computere (servere) uden at være baseret på markedspriser. Open source-programmer optræder derfor som fællesressourcer med et sæt institutionelle rammer for udvikling, udbygning og udnyttelse. Disse programmer er med andre ord ikke statiske eller konstante, hvorved de får stadig ny økonomisk værdi.

Forklaringen på andre begrænsende forhold ved information og data fremlægges herunder.

\section{Information og data}

Information kan modelleres som en kompositorisk triade til forskel fra information som en flerhed af dimensioner eller et bundt af egenskaber (Pedersen 1996). Triaden består af et tidsløst (1) objekt (f.eks. en bog), (2) epokalitet (tid og sted; bogens referencer) og (3) klassifikation (betydning; kundskabsforudsætninger). Ingen af af disse tre kan reduceres til de andre. Information kan imidlertid udbygges i det uendelige. Vi kan ikke beskrive information ved nogen enkelt (mindste-) enhed eller ved nogen enkel kompositionsregel. Tilsvarende gælder iøvrigt for kundskaber.

Der sker et markant skifte i information, når denne bliver udtrykt i digitale data, hvor vi koder information med et opfundet system, for eksempel det binære ASCI-system som i 7 bits definerer alfabetet, de naturlige tal og en række symboler. Her findes der en mindstenhed, en bit $(0,1)$. Og en mindste kommunikerende enhed, baud (puls per sekund). Med skiftet fra information til digitale data optræder der nye regler sammenlignet med dem, som gælder information formidlet i levende kommunikation.

Alle digitale data skal vedligeholdes og opdateres i deres pågældende kontekster og institutionelle rammer, selvom de som digitale objekter kunne eksistere uforanderligt. Data vedligeholdelsen sker ved at knytte data-kontekster og metadata sammen med data-elementerne. Den digitaliserede information - data - har en "naturlig" henfaldstid, fordi referencerne, som indgår i skabelsen af data, er ikke-evige og ikke-statiske uden for det digitale univers.

Digitaliseret information kan konstrueres med nye, fælles egenskaber, hvor deres krav om informationsspecificitet (relevans, aktualitet, knaphed) samt pålidelighed og ansvarlighed beror på institutionelle relationer, som hver virksomhed selv må opbygge (se senere om governance). 
Konklusionen er, at digitaliseret information er allerede indlejret i institutionelle relationer omend med stærkt varierende kriterier. Det er et eksistensvilkår for digitalisering. Digitalisering som form for information lader sig imidlertid underkaste meget forskellige restriktioner.

Det er med avancerede sammenkoblinger i data-kæder i interorganisatoriske, institutionelle relationer, som grundlag for dannelse af en datacyklus, at muligheden for frembringelse af en ny digital fællesressource opstår. Det er med en datacyklus, at vi finder muligheder for en ny værdiskabelse, som vi skal se i det følgende afsnit.

Blandt andet giver disse systemer mulighed for digital modellering af virksomheder (Pedersen 1996). Til forskel fra de før-industrielle virksomheder, opererer nutidens virksomheder i et kontrolregime, som går langt ud over den kontrol, det enkelte menneske kan udøve. De globaliserede markeder skaber et tempo og nogle krav til en storskala koordinering, der kræver en tilsvarende udvikling af informationsskabelse, deling og -behandling (Beniger 1986). Information bliver skaleret til multinational og global størrelse med digitaliseret information, der kan anvendes effektivt til koordinering og beslutninger (Pedersen 1996, s. 280).

Digitaliseringen er blevet en forudsætning for moderne virksomhedsdrift, der drives til at adoptere en procesmodel i stedet for en mekanisk, strukturel, statisk model, divisionsopdelt eller ej.

Informationsudveksling indenfor og imellem virksomhedens enheder omdannes til digitale ressourcer, en datacyklus, der kræver en eksplicit logik med tilhørende styring for at blive opsamlet og blive anvendelig som beslutningsgrundlag, der styrer, sammenkobler og koordinerer de funktions- og geografisk opdelte enheder med tilhørende markeder. Konceptuelt kan den moderne virksomheds datacyklus beskrives som et distribueret vidensnetværk (Pedersen \& Larsen 2005).

Det er i lyset heraf, at vi ser på mulighederne for at skabe digitale fællesressourcer.

\section{Fra personae til agens i informationssamfundet}

\section{Digitale personae}

I informationssamfundet har vi digitale personae, der optræder på internettet. Hver borger som har således en eller flere digitale personae - deres mailadresser som er digitale agenter - der kan modtage og sende meddelelser, audio, videoer, etc. til andre digitale agenter og deres mailbokse.

Eksemplerne er utallige og så almindelige, at det alene er den vinkel, der her anlægges på personae, det er værd at hæfte sig ved. En vinkel som tilsiger, at disse digitale personae teknologisk set kan konstrueres uden, at der er en faktuel, modsvarig levende person. Det ser vi i "games" som bygger på konstruktioner af upersonlige personae omend navngivne, som om de var det. Børnene, der spiller disse "games", er ikke i tvivl om, at der er tale om konstruktioner. Hvordan kan børnene se 
forskellen til personlige personae? For børnene ligger svaret i applikationen, dvs. den valgte applikation (game) sætter nogle rammer, som afgør hvilken natur, der er referencen for hvad, der foregår og for hvem, der er handlingernes subjekter. Således indrammet er disse digitale personae legekammerater for børn og voksne.

En ny problematik opstår, når der ikke længere er klarhed om hvem og hvor handlingens subjekt befinder sig eller, hvad "det" gør. Når den personlige digitale personae ikke findes, men der finder digitale handlinger sted over for den person, der benytter PC'en, smartphone eller anden udstyr, så har vi bevæget os over i det digitale univers uden digitale personae. Dette forekommer i "cookies", “api’ere og i "blockchains”, som vi vil se nøjere på i de følgende afsnit.

Falder kunstig intelligens ind under samme type af agens? Kunstig intelligens omfatter mange forskelligartede teknologier, hvoraf nogle formidler handlinger uden at have reference til en persons digitale personae. Det er tilfældet i f.eks. "Rejseplanen", såvel som i alle andre web-baserede systemer, der alene kræver objekt, tids- og steddata men ingen personlige, er baseret på API'ere.

Andre typer af kunstig intelligens har til formål at virke som digitale hjælpere til den person, der ønsker hjælpen. Det kan være "kontekst-afhængig" støtte til personens bestilling af varer på nettet eller en grammatisk hjælpefunktion i et tekstbehandlingsprogram. Hvor går grænsen for at tale om kunstig intelligens i stedet for blot at kalde noget for en "funktionalitet"? Svaret er, at kunstig intelligens er en konstruktion som en person ikke kan skelne fra, om det er et andet menneske, der hjælper, betegnet Turing-testen (Turing 1950). Dreyfus \& Dreyfus (1986) har også bidraget til debatten, idet de benægter muligheden af kunstig intelligens på samme niveau som menneskets "højeste" intelligens, som de forbinder med udøvelsen af ekspertise, hvor regler og hidtidige erfaringer ikke længere rækker overfor, det nye eksperten står overfor. Selvom det er et relevant emne for afklaring af nye typer af agens, kan kunstig intelligens ikke rummes inden for denne artikels rammer.

Vi vil derimod analysere de egenskaber, der er ved de nye typer af upersonlige, teknologiske aktører, betegnet digital agens og bortser fra kunstig intelligens.

\section{Digital agens}

Når der er aktører i informationssamfundet - som eksisterer on-line, men ingen eksistens har offline - har vi at gøre med en digital agens. Det er umuligt at se andet end aftrykket af dette univers i sine "konsekvenser", ganske som vi ikke kan se elektrisk spænding på anden måde end i sine effekter.

De digitale universer er ikke "færdige" universer med velbeskrevne grænser. De er ikke mindre "uendelige" end det astronomiske univers. Man kan vel sige, at det er en del af universet per se - lige så lidt synligt som de fjerne stjernetåger, som kun kan "ses” i deres effekter, som er radio-bølger. 
De digitale universer kan nemt blive “dæmoniseret”, fordi de er usynlige. Aktuelt er dæmonisering af de digitale universer blevet et udbredt politiseret emne i USA, fordi hacking og cyberkrigsførelse afsløres hyppigere og med stadig voldsommere konsekvenser. I cyberangreb er det et centralt problem at afsløre hvem, der står bag angrebene. Hvilket netop ofte viser sig nær umuligt at afklare. I de digitale universer har flere typer af usynlige og upersonlige digitale agens huseret i mange år. I de næste afsnit beskrives tre typer af digitale agens og hvad der er karakteristisk ved dem hver især. Den sidstnævnte er en ny type, der er på vej.

\section{Anvendelse af digital agens: Cookies}

Den første er "cookies”, som er simple små programmer, som opsøger værter (ligesom en virus) og efterlades på "værten” (server/harddisk) og dér udfører sine aktioner. Disse kan spænde over alt fra opsamling og vidersendelse af "tastetryk" til overvågning af besøg på internettet og videresendelse af IP-adresser til en modtager eller til flere anonyme modtagere som ved et hackerangreb.

De små programmer - cookies - afleveres ved en søgning på internettet fra de søgte websteder og efterlades af browseren på personen's maskinen med mindre dette aktivt forhindres. Informationen i cookies kan være personens digitale identitet, transaktionsdata, m.v., hvilket en senere søgning og relaterede web-reklamer bliver påvirket af. Det står ikke klart for personen, hvem der får hvilke personlige data og net adfærds historik (der henvises blot til "tredjepart"). Med persondatalovgivningen (som følger GDPR direktivet fra EU) har brugerne opnået ret til at begrænse anvendelse af cookies (Erhvervsstyrelsen om cookies, 2019).

Efter den seneste ændring af persondataloven skal enhver borger have at vide, hvilke data der afgives til hvem, og hvorvidt de ønsker at stoppe dataafgivelsen for nogle kategorier af modtagere eller for alle kategorier. I sidstnævnte tilfælde kan borgeren opleve at miste adgang til den oprindeligt søgte service, fordi denne service ikke vil oplyse, hvem "tredjeparterne" er.

I centrum for udnyttelsen af cookies er den maskine, som kan koble en vilkårlig borger til en specifik annoncør, og som derfor er enhver cookie's "livsbetingelse”. Uden Google ville det blive yderst begrænset, hvilke borgere som kunne knyttes til hvilke annoncører. For at prioritere hvilke borgere, der skal kobles til hvilke annoncører, når der er flere af sidstnævnte, som alle ønsker koblingen, griber Google til at anvende forskellige redskaber, lige fra priser til at udvælge dem, som de selv har investor-interesser knyttet til. Google’s søgemaskine er verdensomspændende og et de facto monopol i den vestlige verden. I over et år er Googles monopolstilling blevet undersøgt af US myndigheder, som overvejer at rejse en monopol-sag imod Googles ejere (iflg. Washington Post 249-2020).

Den videre betydning af cookies for udviklingen af digital agens findes i måden at skabe data. For brugeren er det "umærkeligt" og usynligt. Derfor er skabelsen af data ikke umiddelbart manipulerbar for brugeren selv. Vi taler om en "unobtrusive measure" af data, som er uforfalskede 
med ukompromitteret troværdighed (Webb et al. 1966). Sådanne data har en særlig værdi i modsætning til data, som er påvirkede af for eksempel en interviewer, eller som datagiveren selv ønsker at manipulere af en eller anden grund. De "unobtrusive" data er dog ikke nødvendigvis gyldige af den grund, at de aldrig kan blive bedre end de fortolkninger, som gyldigt kan lægges ind over de opsamlede data. Pålidelighed kan være fuldstændig samtidig med at gyldigheds-kriterierne ikke er opfyldte.

Det næste led i datakæder er den server, som styrer koblingen af cookies data med de interesserede brugere af disse data. Den kan være ejet af mere eller mindre kendte interessenter, alt afhængig af, hvad cookien er beregnet til. Hvis data kun afleveres til én bestemt interessent - gerne via et meget stort antal mellemstationer - vil disse data formentligt blive anvendt af kriminelle, hackere og spioner, etc. Uden at brugeren er klar over cookiens eksistens. Cookies kan i princippet være meget åbne og uskyldige, når de blot indsamler data til et statistisk formål for en bred gruppe af interessenter, f.eks. udviklere til en applikation med mulighed for fejlfinding og med henblik på forbedring af app'ens performance.

I digital kommunikation er det blevet uoverskueligt for den enkelte bruger at afklare konsekvenserne af tilsagn om anvendelse af en cookie.

Det rejser umiddelbart etiske spørgsmål, udfordrer retten til privatliv og ikke mindst sætter spørgsmålstegn ved enhver påstand om sikkerhed for data autencitet, integritet og afsendermodtager overensstemmelse i enhver datakommunikation. Værdiskabelsen for den enkelte bruger kan derfor være meget diffus. Derimod kan den tredjepart, som får del i data om brugeren, udnytte disse til egne formål. Det kan være målrettet markedsføring, profileringer til segmenteringer af et marked, eller til begrænsning af beregningstid ved brugerens anvendelse af sin browser til opslag på internettet, hvor en søgemaskine kan udnytte cookies til hurtig afgrænsning af søgeområdet.

Governance for cookies er centreret om søgemaskinerne, som er private platforme med stærkt begrænsede kommunikative fællesskaber med brugerne og de interessenter, som også får del i profileringsdata om brugeren.

I applikationer skal cookies deklareres for brugeren, men det sker i overordnede og generelle vendinger, som lader meget tilbage at ønske, hvad angår transparens. Endvidere er der ofte et minimumskrav om accept af nogle cookies for overhovedet at få adgang til at bruge applikationen. Siden EU's direktiv om persondataloven er frihedsgraderne for cookies indsnævret, men de grundlæggende udfordringer er ikke løst, som flere og flere sager om overskridelser af persondataloven vidner om.

Cookies lever videre men med flere begrænsninger og en ny offentlig opmærksomhed som følge af kravet om at deklarere dem som forudsætning for anvendelse af programmet, hvortil de er knyttet. 
Cookies, sådan som de er anvendt, giver ikke grundlag for dannelse af forudsætninger for digitale fællesressourcer.

\section{Anvendelse af digital agens: API}

Den anden type af digital agens er API'ere. API står for "application programming interface”, som henviser til en gensidig sammenkobling og udveksling af procedurer, metadata og datasæt imellem forskellige programmer og computere. API'ere er blevet et stærkt værktøj for udvikling af services, der udnytter internettets globale udbredelse og åbne standarder for kommunikation (Jacobsson et al 2012).

Hvert eneste program har grænsesnit til det styrende, underliggende operativsystem. Det har over årene hermed udviklet utallige nye faciliteter til understøttelse af digitale tredjeparters operationer uden at reducere systemets svartider nævneværdigt. Apps udstyres med stadig flere api-grænsesnit til andre programmer og stiller krav til disse andre programmer, hvad angår sikkerhed, tilgængelighed, svartider, opdateringer, etc. Vilkår for API'ere fastsættes af ejerne af operativsystemer, heriblandt Microsoft, Google, Apple, Samsung, IBM, Linux, SAP, Oracle, Facebook og Twitter.

Eksempler på API'ere er utallige eftersom en helt afgørende del af de digitale services, som en computer, tablet eller smartphone kan stille til rådighed, baserer sig på API'ere. F.eks. kan Rejseplanen ikke fungere uden at computerens operativsystem er opbygget med interfaces til netbaserede services bestående af såvel geografiske applikationer med kortdata og til tog-, bus- og metroselskabers køreplaner og aktuelle driftsstatus på hver eneste linje og for hvert eneste tog, bus eller metro.

Aktiveringen af et API knytter sig til personens anvendelse af den tilknyttede applikation og således til den service, som personen ønsker udført med sit digitale værktøj. Hvilke data og rutiner applikationen igangsætter og deler med hvem er dog langtfra transparent for personen.

Til hver API transaktion er der knyttet en aktiv handling af personen, der som bruger har tilladt disse ved ibrugtagning af app'en. Tilladelsen kan også medføre, at API'en skjult henter data også på tidspunkter, hvor personen ikke bruger applikationen, men baseret på en generel tilladelse til, at applikationen kan "arbejde i baggrunden”.

Den nyere omlægning af NemID fra nøglekort til nøglefiler er netop baseret på API'er og den kommunikative triade, hvor brugerens digitale værktøj i kraft af forskellige kanaler kan optræde som to selvstændige enheder på henholdsvis internettet og i en SMS-kanal.

Bag bruger-grænsefladen er der adskillige api'er, som afleverer forespørgsler til andre fjernprogrammer og får øjeblikkeligt respons, således at borgeren ikke oplever, at der er tale om et til 
lejligheden selekteret fjern-program, som forsyner vedkommende med et borger-forståeligt svar på de af app'en oversatte data til fjern-programmet, og som har behandlet alle de modtagne data, herunder prioriteret dem eller afvist dem således, at et svar kan præsenteres til borgeren. Alt sker på brøkdele af et sekund!

API'ere optræder i stort set alle apps på computere og andre enheder. Det er en effektiv form for "distribueret databehandling", som effektivt udnytter spredte databaser og deres beregningskapacitet.

Hvorvidt disse API'er skal "deklareres" for borgeren kan diskuteres, fordi de enkelte dataforespørgsler kan ske uden at medsende persondata om borgeren - men alene en kodet "identifikator", der alene gælder for datakommunikationen mellem de to databehandlende enheder. API'ere er altså ikke resultatet af en borgers aktiviteter på nettet, men er indbygget i den app, som borgeren har anskaffet sig og anvender. Hovedparten af de services, som virker nyttige for borgerne, er alle forsynet med en righoldig samling af API'er. Eftersom API'erne tillader veldefinerede servicetyper, er de at forstå som forbedringer af operativsystemers kapacitet for distribueret databehandling. Med transparente aftaler om API'ere kan brugere tage stilling til deres anvendelse i tilknytning til valg af applikationer. Men langtfra alle API'ere bliver deklareret for forbrugerne lige så lidt som for de virksomheder, som anvender applikationer i deres forretning.

Udbredelsen af API'ere har taget fart med udviklingen af applikationer, som umiddelbart kan tages ned fra internettet af den enkelte bruger. Oprettelsen af platforme for distribution af apps (Apple Store, Google Play m.fl.) er en meget betydelig effektivisering af distributionen af applikationer. Samtidig har koncentrationen på platforme stimuleret en betydelig vækst i digitale innovationer. Den udbredte og nemme adgang til applikationer har udvidet og udvider hver dag de digitale universer.

Et eksempel på en "eksplosiv" udvidelse fandt sted i 2011, da Netflix begyndte at streame TV over internettet med brug af API'ere. Omkring 30\% af internettet lagde Netflix beslag på i det år i USA (Jacobsson et al 2012, s.33). Udover Netflix er SalesForce og Amazon Web Services bygget op omkring APi'ere. Facebook og Twitter er senere kommet til og har ligeledes udvidet de digitale universer, hvor API'ere har en afgørende betydning.

Med andre ord kan vi ikke forestille os nutidens digitale universer uden API'ere. Deres opbygning udelukker ikke muligheden for at skabe fællesressourcer, men deres anvendelse er sket som en udbygning af privatøkonomiske profitmuligheder, hvor der samtidig er sket en eksplosiv udvidelse i anvendelsen af cookies i tilknytning til de mange nye applikationer med API'ere. Cookies indsamler data, API'ere behandler data. 
Den digitale økonomi - hvilken Arthur (2011) betegner den "anden økonomi” - er sket entydigt med vægt på de privatøkonomiske muligheder for virksomhederne. Applikationer som Netflix, Facebook og lignende falder ind under underholdningsindustrien. Deres værdi for brugerne ses i brugerbetalingen i form af abonnementer og i accept af adgang til dataprofilering som grundlag for leverandørens indtjening, fortrinsvis ved vidersalg til tredjepart.

\section{Anvendelse af digital agens: Blockchains}

Megen teknologi kommer som færdige løsninger fra leverandørerne, som tilfældet er med API'ere. I den henseende er blockchain en anden slags teknologi. Forskellen er "teknologi som løsning” eller som "institutionel afhængig teknologi”. Hvad betyder forskellen?

Blockchain er en "komposition" af teknologier, der hver især kan noget, men som ikke kan stå alene. Til forskel fra API'er er blockchains nødt til at gå "hele vejen” i udnyttelsen af kommunikation og skabelse af fællesressourcer for at blive til det, som giver deres berettigelse. Blockchains er en ny institutionel teknologi forstået således, at der ikke kan opsættes en enkelt eller ganske få teknologier som grundlag for en løsning til brugeren. Det er derfor nærliggende at relatere blockchains til de ny værdiskabende fællesressourcer inspireret af Ostrom.

For at forstå blockchains gives herunder nogle eksempler på dem.

\section{a. Blochains i cryptovalutaen Bitcoins}

I sin mest outrerede form for blockchain findes crypto-valutaen Bitcoins og hundredevis af beslægtede "coins" - digitale penge. Denne type af blockchain har flere institutionelle relationer.

Den ene er "konsensus" mekanismen, som skal sikre, at transaktioner er "gyldige" inden for den logik, at "penge" kun kan bruges en ad gangen omend igen og igen, altså at den samme krone kun kan anvende til køb én gang på et givent tidspunkt, samtidig med at den kan opbevares fortsat, altså at den ikke "konsumeres i transaktionen".

Hvor en API'-behandlet transaktion "forsvinder" i samme øjeblik, at transaktionen er fuldført, så vil blockchains bevarer alle transaktioner, ligesom Bitcoins "bevarer" sine "coins", som om de var "fysiske" enheder. Metoden er at danne "blocks" af en samling af transaktioner inden for en relativ kort tidsramme (p.t. omkring 10 minutter), hvorefter disse krypteres med brug af seneste tidligere blocks kryptering. Deraf betegnelsen "kæde”. Hvert led i den fortsat opbyggede kæde lægges til efter en konsensus-periode, hvor et automatisk programskabt matematisk spørgsmål skal finde sin matematiske løsning, og den, som er den første (af rigtig mange mulige) matematiske besvarelser, bliver "broadcastet" til alle brugere af bitcoins-appen, hvor dens "overlevelse" som gyldigt svar er betinget af, at mindst 50\% af alle aktive net-aktive enheder godkender det. Denne "konsensusmekanisme" er en speciel form for institutionel løsning på et sikkerhedsproblem, som hedder "man in the middle", hvor enhver kommunikation risikerer at blive afluret af en tredjepart, uden at de kommunikerende parter opdager dette, hvilket betyder, at parterne ikke ved, om det er det 
oprindelige datasæt, som er nået frem til modtager, og omvendt om det tiltænkte svar er nået tilbage til spørgeren. Et problem ved den valgte konsensusmekanisme er, at blokkene vokser og vokser, hvorved databehandlingskapaciteten til at sikre enhver ny blok bliver større og større. Hvor stort er ufatteligt eftersom, der er tale om et el-forbrug større end mange nationers!

Der er andre sikkerhedsrisici, som håndteres i forbindelse med "konsensus-mekanismen" vedrørende "transparens", hvilket vil sige, at alle transaktioner kan følges af alle digitale agenter. Aktørerne i cryptovaluta er digitale personae sikret anonymitet.

Den anden institutionelle faktor i bitcoins knytter sig til den ramme, som er indbygget i programmet. Først og fremmest er en bitcoin uendeligt opdelelig til forskel fra "kroner og ører", som kommer i form af størrelser - lige fra $1000 \mathrm{kr}$. sedlen til 25 øren - men samtidig har bitcoins en total størrelsesbegrænsning, nemlig at der kun kan skabes et endeligt antal hele bitcoins, nemlig 21 millioner bitcoins. Dette er institutionelt fastsat af programudviklerne en gang for alle. For at øge transaktionsantallet har det vist sig muligt at underopdele enhver bitcoins vilkårligt meget, således at der kan handles med brøkdele af en bitcoin. Det peger i retning af en uendelig valuta, jo mere uendelig jo større værdien bliver af den enkelte bitcoin, som værdimæssigt meningsfyldt lader sig opdele i stadig mindre dele.

Enhver konvertibel valuta til forskel fra bitcoins, som ikke er konvertibel, har ingen forhåndsfastsat mængdebegrænsning. At bitcoins har en værdi i forhold til US-dollar er udtryk for, at bitcoins kan købes i andre valutaer men ikke, at der er en officiel kursværdi overfor andre konvertible valutaer. Dollarværdien af bitcoins er vokset til gigantiske beløb - over 20.000 US \$ i det seneste år - men fluktuerer voldsomt. Salg af bitcoins imod dollars er altså en spekulativ forretning. Der er ingen centralbank, som støtter bitcoins og derfor er Bitcoins ikke anerkendt som et gyldigt betalingsmiddel. Den har i myndighedernes øjne karakter af en lodseddel, en indsats i et casino eller et pyramidespil. Ikke desto mindre er der mange spillere i verden omend, de tilsyneladende har meget forskellige motiver for at spille med på dette casino (jf. Pedersen 2018).

I en tid med avisoverskrifter om hvidvaskning og skatteunddragelse burde bitcoins og andre successrige cryptovalutaer indtage en fremtrædende plads, da det skønnes at Bitcoins samlede værdi er flere hundrede milliarder dollars.

Bitcoins er dog blot én og en meget speciel udmøntning af blockchains! Der er andre mindre spekulative løsninger og anvendelser, som ikke kræver den meget specielle form for "konsensus" mekanisme, der anvendes i Bitcoins, men regulerer sin værdi bundet til en officiel dollarkurs (i forhold til en valgt anden valuta). 


\section{b. Blockchains til opsporing}

Blockchains kan indgå i kommerciel anvendelse, hvor det er interessant at kunne "spore" oprindelsen af et produkt. Hvor bitcoins havde fokus på "blocks", så har andre anvendelser fokus på "chains". Dette refererer til sporbarhed, som bitcoins er ganske ringe til, fordi de digitale aktører er anonyme og tilsyneladende sætter meget stor pris på at forblive anonyme.

En grund til, at sporbarhed kan være værdifuldt for en virksomhed, kan være ønsket om at identificere en fejlkilde. F.eks. har Walmart vist, at de ønsker at kunne spore fra, hvilke leverandører rådne meloner og grøntsager kommer. Med blockchains har det vist sig muligt at spore kilden på timer i stedet for ved et større detektivarbejde, som tager dage. Hurtighed i opsporing er ensbetydende med hurtighed i indgriben overfor en kilde til tab. Walmart har publiceret dette som et succesrigt forsøg med blockchains anvendt til afgørelse af oprindelse.

Et andet eksempel på anvendelse af blockchains knytter sig til sundhedsdata. Her er sikkerhed og aktualitet afgørende for bedst mulig patientbehandling både diagnostisk og i den efterfølgende behandling. Blockchains kan bygges således, at sundhedsdata følger patienten, uanset om vedkommende nyligt er flyttet til en anden landsdel (region) eller befinder sig i udlandet. Udveksling af realtidsdata finder ikke sted i dag, fordi data opsamles i sundhedsdatabasen, som har en cyklus i forhold til de forskellige hospitaler. I en distribueret løsning som blockchains vil de aktuelt gældende data altid stå til rådighed, uanset hvor i landet borgeren befinder sig, f.eks. ved en ulykke.

\section{c. Blockchains i sundhedsektoren: Smitte-stop app}

Har vi eksempler på anvendelse af blockchains i sundhedssektoren? Svaret er ja! Smitte-appen.

I løbet af relativ få måneder har to af verdens største IT-virksomheder, Apple og Google, samarbejdet om at udvikle en app til smitte-opsporing af COVID-19. Denne app udviser klart egenskaber, der kan knyttes til logikken i en blockchain, som er radikalt distributiv, idet løsningen ikke beror på en enkelt ejer af data. Der er programadministratorer, nemlig de to selskabers udviklingsafdelinger, men de er det kun hvad angår algoritmerne, men ikke hvad angår de data, som behandles eller de servere, som knyttes til dataalarmen fra den enkelte bruger.

Data skabes automatisk ved, at mobilenheden registrerer andre mobilenheder i sin nærhed med bluetooth kommunikation, som opfanger andre bluetooth sender/modtagere inden for en begrænset radius og for en afgrænset tidsperiode. Bluetooth er en fast indbygget del af alle mobilenheder og tjener en bred vifte af apps. Mobilenheden lagrer alle de nære mobilenheders (unikke) enheds-navne, som er tilfældigt genererede ID'er. Dertil dato for kontakten, varigheden og signalstyrken, som samlet kan danne et datasæt, der muliggør at en eventuelt smittet kan udsende besked til de ID'ere, som har været i nærheden inden for en 14 dags periode, fra tidspunktet for en positiv test er kendt. Det er den periode, inden for hvilken en eventuelt uopdaget smitte, vil kunne nå at bryde ud og blive testet og borgeren får respons. Hvis en test viser sig positiv, videregiver borgeren denne information på mobilen, hvorefter alle mobilenheder, som har været i nærheden i 
den forudgående periode, bliver underrettet om, at de har været i nærheden af en nu smittet, anonym person, hvorfor de, såfremt de ikke allerede har fået konstateret sygdommen, bør blive testet snarest muligt. Alle data fra før de forudgående 14 dage slettes løbende på mobilenheden. Der opbygges således en tidsafgrænset blockchain, hvilket giver god mening i en pandemisk sammenhæng.

Data er ikke tilgængelige for borgeren på anden måde end, at de kan tilgå app'en og afgive eller modtage data om smitte. Hvilke borgere, vedkommende har været i nærheden af, forbliver anonymt. Den løbende sletning af data, som er ældre end 14 dage, sikrer, at der ikke sker en dataopsamling om den enkelte borgers adfærd, ligesom det undgås at blockchains datakrav vokser og vokser sådan, som det er tilfældet i Bitcoins. Således er de digitale sociale relationer af en hel anden art end de reelle sociale relationer. Kun digitale relationer kan sikre fællesressources tilblivelse og udvikling, fordi de er baseret på digital agens.

Smitte-appen er et eksempel på en distribueret dataopsamling med fuld sikring imod adgang til misbrug af personoplysninger, fordi den danner "unobtrusive" data. Misbrug af oplysninger kunne skabes, hvis smitte-appen havde adgang til andre apps på borgerens mobilenhed og skjult kunne sende disse data til den centrale udviklers selskab. Både Apple og Google har forsikret om, at et sådant misbrug overhovedet ikke kan finde sted med den pågældende app’s teknologi.

Hvad angår persondatalovens beskyttelseskrav i tilknytning til denne app så opfyldes disse, til dels ved selve sikringen af, at app'en er beskyttet imod angreb og imod alle forsøg på at overtage dens data, samtidig med, at brugeren har fuld ret til at slette sin app og dermed alle data men uden at kunne se disse datas oprindelse, da datakæden løbende krypteres af applikationen. Krypteringslogikken er den successiv kryptering, som karakteriserer blockchains.

Apple og Google har også skabt sikkerhed ved at anvende deres app-stores som distributionscentraler, hvor de hver især udøver kontrol med app'en. Den institutionelle relation mellem udvikler og slutbruger går således over et distributionsled, som de respektive selskaber har fuld håndsret over, hvad giver dem væsentlig sikkerhed for app'ens autencitet og integritet.

I Danmark har app'en været genstand for en tilbygning af en institutionel relation under anvendelse af et til rådighed stillet API fra Google og Apple. Den danske udgave er udviklet af Sundheds- og Aldreministeriet. Styrelsen for Patientsikkerhed har ansvaret for app'en og oplyser, at hverken styrelsen eller andre har adgang til de lagrede data. I Danmark bliver data slettet automatisk efter 14 dages lagring. Hvis en borger lader sig teste, bliver testresultatet, hvis positivt lagt ind i en fælles database, "mikrobiologidatabasen” (MiBA). Her ligger oplysninger om alle COVID-19 positivt testede danskere sammen med deres cpr-numre. Borgeren får besked om testresultatet via e-boks under anvendelse af sin NemId adgang hertil. Samme oplysning bliver automatisk hentet af smittestopapp'en, når borgeren bruger Smittestop-app'en, der viderebringer oplysningen til de (skjulte) 
medborgere, som vedkommende måtte have været i nærheden af i de forudgående 14 dage. App'en får besked fra registret "ved hjælp af en anonym ID-nøgle og dermed uden at app'en får adgang til brugerens navn eller personnummer", skriver smittestop.dk.

Derfor er der tale om en offentlig blockchain med en central myndigheds garanti for sikker datalagring, ligesom at kommunikation om smitte afgives med anvendelse af NemID, hvorved der anvendes en krypteret, sikker datakommunikation udviklet her i landet. Dette er et institutionelt forhold ved den danske version af smitte-app'en, hvad der kan betegnes som "lokalisering” i udvikler-jargon. Nedtagning og anvendelse af app'en er helt frivillig og kan efterfølges af borgerens egen sletning af app'en på et hvilket som helst tidspunkt, hvorfor app'en er i overensstemmelse med persondataloven på dette punkt. Sikkerhed imod falske meddelelser om smitte ved anvendelse af app'en er opnået med koblingen til Covid-databasen, hvorfor troværdigheden på dette punkt er sikret. Teknologiens præcision i registrering af "person-i-nærhed" er ikke fuldkommen. Nærtstående pårørende bør derfor advares direkte under alle omstændigheder.

App'en blev frigivet i juni måned 2020. Den 28. januar 2021 var app'en i Danmark nedtaget af 2.140.591 (se: smittestop.dk). I denne størrelsesorden må app'en kunne blive en væsentlig kilde til opsporing af smittekæder og derved forøge muligheden for at bryde dem, ved at borgerne bliver testet og går i isolation, hvis testen er positiv.

En pointe i denne historie er det, som ikke nævnes, nemlig at mange lande først igangsatte egne udviklingsafdelinger til at udvikle en app med ovennævnte egenskaber. Det blev dog hurtigt opgivet - selv af store lande som Storbritannien - da kompleksiteten syntes at overstige formåen, men især fordi de centrale teknologier, der indgår i app'en ikke er frit tilgængelige, men en del af de kærneområder inden for software lagret på ASICs (application specific integrated circuits) de store IT selskaber benytter sig af til at skjule dele af deres systemkoder. Uden adgang hertil ville enhver anden løsning være henvist til "de højere software lag”, som det ville være langt vanskeligere at beskytte imod angreb og misbrug. Sikkerhed i smittestop-appen beror på "hardwired software".

Sammenlignet med cookies og API'ere er blockchains en meget avanceret teknologi, som involverer institutionelle relationer i en endnu højre grad end hvad, der er tilfældet for andre digitale agens.

Når vi tager det skridt at vurdere blockchains som en ny teknologisk konstruktion med en på forhånd nødvendig indbygning af udfoldede institutionelle relationer, er det ikke, fordi forskellene mellem cookies, API'er og blockchains nødvendigvis behøver at være så væsentlige. Det er snarere udtryk for en historisk udvikling, nemlig fra en "blind" accept af ny teknologi som et fremskridt til en tid, hvor ny teknologi efterprøves og udfordres af kompetente myndigheder, brugere og borgere. Sidstnævnte kræver mere sikkerhed med tiden også som udtryk for, at flere og flere personlige oplysninger nu ligger digitalt. Hvis ikke der foretages særlige tiltag af institutionel karakter, vil brugen blive meget mindre sikker og følgelig vil færre benytte sig af den. 
Tiden er til større sikkerhed for, at data ikke flyder til de kriminelle, som forsøger at skabe sig en levevej på andre borgeres data, hvad enten de er pirater, der videresælger eller er hackere, der kræver løsesummer for adgang til borgerens egne data, eller ved at overtage en borgers identitet og udnytte den til bedrageri. Blockchain bidrager med en høj grad af sikkerhed.

Perspektiverne i blockchains er stadig under udforskning og fraværet af flere gennemprøvede og fungerende anvendelser vanskeliggør deling af viden om samspillet mellem teknologiske og institutionelle dele. Iblandt specialister opfattes sidstnævnte som den vanskeligste forhindring for udbredelsen af blockchains. En institutionel del vil altid kræve et nært samarbejde imellem aktørerne for at kunne udnytte et digitalt agens, som er udstyret med et "selvstændigt" repertoire af handlemuligheder. Tilvejebringelse af de institutionelle rammer har vist sig vanskelige. Et eksempel er Maersk.

Maersk's konsortium af redere, havneterminaler, toldmyndigheder og speditører med mere end 90 deltagere vil bygge blockchains til deres håndtering af containere verden over. Oprindeligt blev projektet startet som et fælles projekt mellem Maersk og IBM, men de institutionelle faktorer og incitamentoverensstemmelse mellem parterne har medført, at de to"kæmper” ikke kunne realisere et sådant blockchain projekt alene. De mange led i kæden skal have incitament til at deltage og opretholde kædens integritet med rette kompetencer og kapabiliteter samt indgå i institutionelle relationer om bl.a. monitorering og datakvalitetssikring, for at kæden opretholdes operativt (jf. Berlingske Tidende 25.9.2020).

Blockchain har et krav om fællesskab, hvad enten det er i en supply-chain som hos Maersk eller det er i opspring af pandemisk smitte i en befolkning. Arbejdet med at skabe og opretholde fællesskabet kræver, at der er incitamenter for deltagelse for alle parter. Når disse betingelser skal opstilles, er der brug for en institutionel ramme. En sådan har Ostrom et al opstillet. Når den udformes digitalt, fordi mængden af transaktioner og deltagere nødvendiggør dette, så må den valgte løsning også sikre de mange deltagere imod falske aktører, brud på datasikkerhed og privatliv, etc. Blockchain har i sin kærne en sikkerhed, der er blandt de bedst mulige i dag.

Fællesværdi fra blockchain er det muligt at opnå ved at hver enkelt deltager har adgang til de digitale fællesressourcer - i smitte-stop er det koblingen af tests og mikrobiologidatabasen - og selv bliver løbende indlejret i smitte-stop kæder for hver eneste app-bruger, vedkommende er i nærheden af for en tidsperiode (ca. 15 min.). Opnåelsen af afdækning af en realiseret smitte-risiko er et enestående resultat, som kun kan lade sig gøre ved brug af digital agens, som arbejder ustandseligt og 24/7 uanset hvem der er brugeren, og uanset hvilken omgangskreds brugeren har. Voerdien af en sådan risiko-afdækning er betydelig for bekæmpelsen af den fælles risiko ved at blive syg i en pandemi. Derfor er værdien af fællesressourcen også aftagende med pandemiens aftagen. 


\section{Socio-økonomiske muligheder med digital agens}

Vi har i forrige afsnit fremlagt et eksempel på en utvivlsomt værdiskabende anvendelse af blockchains. En anvendelse, som meget klart viser, at de institutionelle faktorer er afgørende for dels ibrugtagning af en app, dels for en effektiv anvendelse ved tilkobling af testmyndigheder, dels en effekt, som er helt uafhængig af den enkelte borgers adfærd inden for de institutionelle rammer, idet brugen af app'en er automatiseret. Således muliggør appen en digital fællesressource.

Blockchains i sig selv garanterer ikke økonomisk værdi. Det institutionelle set-up er afgørende for værdiskabelsen.

Der er stor interesse for blockchains globalt. Dels foregår der en international standardisering i ISO, og dels laver mange virksomheder forsøg. Også danske myndigheder er igang med forsøg, f.eks. er Søfartsstyrelsen igang med et projekt om et internationalt skibsregister baseret på blockchains.

Industriel anvendelse af blockchains kan findes $i$ udnyttelsen af avancerede dataindsamlingsmetoder. Sensorer anbragt i lastbilens dæk er et eksempel på en dataopsamling, som kan anvendes til at måle dækkets slidbanetykkelse og dermed bestemme tidspunkt og sted for skift af dæk (Pedersen 2019). Her er der tale om omkostningsreduktion på den ene side - at der er kortere servicetid, fordi tid og sted er forberedte på skiftet - og økonomisk gevinst på den anden side, fordi der kan køres længere på dækket uden at risikere tilfældige driftsstop eller ulykker. Tidspunkt for skiftet er ikke afhængigt af chaufføren.

I hvert tilfælde kan vi se, at kæder af data kommunikeres hurtigere og sikrere i institutionelt fastlagte rammer end økonomiske markedstransaktioner og medvirker derved til, at omkostninger ved økonomisk aktivitet kan nedbringes. Spild reduceres. Fejlkilder opspores hurtigt. Anvendelsen har lave driftsomkostninger. Kort sagt, såfremt en fællesressource identificeres og et fællesskab opbygges institutionelt er deltagerne på vej til et økonomisk resultat baseret på det fælles gode.

De socio-økonomiske effekter af blockchains, der er institutionelt forankret, skal ikke konkret klarlægges på dette tidspunkt i udbredelsen af anvendelse, men smitte-stop appen er kandidat til en række af målinger.

\section{E. Regulatoriske udfordringer}

Som følge af den teknologiske udvikling er det ikke muligt at kende grænserne for teknologierne, men det er et godt bud at sammenligne de digitale teknologier med vores naturlige sprog. Det har været et forskningsresultat i mere end 50 år, at sproget ikke rummer en grammatisk defineret grænse, men tværtimod har et uafgrænset, grammatisk potentiale. Tilsvarende har filosoffer hævdet, at den digitale logik er nært beslægtet med opbygningen af menneskets hjerne. Betragtet i 
et historisk lys har de digitale teknologier bredt sig fra beregninger til tekstbehandling, til digitalisering af lyd, billede, film, og forandringerne har endnu ikke set deres afslutning.

Derfor kan det virke ambitiøst at opstille regulatoriske rammer for digitalisering. Ikke desto mindre er det set med GDPR - på dansk persondataloven - som forsøger at formulere, hvad der kan kaldes strategiske compliance betingelser (Pedersen 2015, 2016-17).

Regulatorisk er compliancekrav et vanskeligt felt at arbejde i, fordi indfrielse af et sæt af krav sjældent kan være udtømmende beskrevet således, at de deklarerede formål fuldt kan indfries. Problemet er kendt fra skattelovgivningen.

Med GDPR er der formuleret en anden måde at regulere på. Der er ikke tale om en "ramme", men om en kommunikeret ansvarlighed for egne forhold under henvisning til en række alment formulerede formål. Kravene er ikke “operationelt definerede”. Det giver selvfølgelig usikkerhed hos virksomheder og organisationer, som er forpligtede på GDPR-direktivet i lyset af bøderisici i anseelig størrelse.

Denne form for regulering tvinger virksomhederne til at efterkomme formålene, altså udvise compliance, men samtidig er det en opfordring til at betragte formålene (i det mindste nogle af dem) som anledning til en forbedret service over for kunder og forretningspartnere. Da enhver GDPRløsning er en lokaliseret, specifik løsning, er det nærliggende at samme løsning skal udformes, så den varetager virksomhedens strategiske interesser. Da GDPR er udspændt over alle enheder i markederne, lægges der op til at etablere institutionelle relationer, som kan have en værdiforøgende betydning for de deltagende virksomheder.

Kunderne kan med andre ord blive vindere på en bedre service, samtidig med at virksomhederne får en bedre forretningsløsning. Eller virksomheden kan lide under disse krav.

Når vi tidligere pegede på digitale fællesressourcer, var sigtet at vise hen til nogle nye muligheder med de digitale teknologier forudsat en institutionel relation. Som teknologisk eksempel er anvendt blockchains. Men andre teknologier kan også danne digitale fællesgoder. De er med andre ord ikke kun knyttet til blockchains.

Med smittestop-appen har vi i praksis vist, at blockchains anvendt på sundhedsdata danner digitale fællesressourcer, som kan komme den enkelte borger til gode med en positiv værdi.

Pointen er at smittestop-appen ikke kan eksistere andre steder end i et digitalt univers, og at den kun kan få værdi, hvis den bliver til en fællesressource, hvilket vil sige, at den har en meget høj udbredelse og bygger på troværdige data. 
De digitale fællesressourcer behøver ikke kun blive tænkt omfattende et helt samfund. Der kan også tænkes en mindre kreds af deltagere, hvilket sker, når der skabes konsortier, som sammen løser et fælles problem, og når disse løsninger indlægges i en institutionel relation, som sikrer at løsningen ikke bliver monopoliseret.

Som et eksempel på opbygning af en kæde, hvor en løsning ikke monopoliseres af enkelte selskaber, er Maersk Rederiets forsøg på opbygning af et konsortium om containerhåndtering.

Et eksempel på monopolisering er en digital fællesressource er Google’s søgemaskine til internettet. Det er ikke en blockchain teknologi, men en "platform", som udgør en "hub" for al datakommunikation mellem dem, der opsøger digital information, og de som ønsker at placere en annoncering tæt på potentielle kunder i realtid. Her har en enkelt aktør overtaget hele markedet i den vestlige verden og således ændret et oplagt fællesgode, som har alle de digitale fællesressources egenskaber bortset fra, at et monopol kan tilegne sig hovedparten af værdiskabelsen, til et privat monopol, som er i stand til at fastholde sin position i kraft af en kombination af skalafordele og netværkseffekter samt ved udøvelse af markedsmagt. Især det sidste har medført, at adskillige virksomheder har klaget over monopolets markedsadfærd. I USA går forberedelserne til et sagsanlæg mere end et år tilbage i tid. Dette monopol bliver udfordret af myndigheder - Department of Justice - i USA (jf Washington Post 23.9.2020; New York Times 22.9.2020).

I kraft af Googles søgemaskine står helt centralt i al annoncering på internettet i den vestlige verden, er selskabet, der ejer Google, Alphabet, blevet en af USA's mest værdifulde målt i markedsværdi.

Digitale fællesressourcer må have en række institutionelle relationer for at virke værdiskabende. Disse er ingenlunde selvindlysende eller sikret af de markedsøkonomiske kræfter. Når de er skabt, kan de bibringe deltagerne gevinster, men også samfundsøkonomien kan gavnes af den højere effektivitet, som disse løsninger muliggør, når de ikke bliver anvendt som grundlag for et monopol.

\section{F. Konklusion}

Digitale fællesressourcer opstår ikke af sig selv. De er afhængige af institutionelle relationer. Disse opstår heller ikke af sig selv. Følgelig ser vi frem til, at flere fællesressourcer bliver realiseret i kraft af, at oplyste borgere stiller krav til udviklingsselskaberne og til de relevante sektorer og aktører i samfundet. Viden om mulighederne er en forudsætning for formulering af kravene til digitalisering. En anden faktor er presserende problemer, som for eksempel er skabt af pandemier, miljøproblemer og klimatrusler.

"Common pool ressources" har deres oprindelse i naturgivne, knappe ressourcer. For disse ressourcer er værdiskabelse blevet mulig som følge af de institutionelle rammers indvirkning på og styring af udnyttelsen. Så længe ressourcen ligger urørt hen i bjerge, i floder og have forbliver den uden værdi. Dette er den markedsøkonomiske logik. Når disse ressourcer udnyttes, er det med et 
økonomisk sigte. Med fællesressource-begrebet, som indebærer en regulatorisk institutionel ramme, må virksomheder gøre op med den uholdbare forestilling om naturen som en uendelig ressource. Og der er et alternativ.

Klima- og miljøproblematikker medfører, at uberørt natur begynder at få en økonomisk værdi omend ikke en markedsøkonomisk, men en global eller regional, direkte såvel som indirekte samfundsøkonomisk betydning. Med andre ord er natur blevet flyttet fra den rene "objekt"tænkning til en grad af "subjekt" i de økonomiske og sociale strukturer, som mennesker konstruerer. Pointen er målbar. Kay Raworth har fremlagt, hvordan i sin "doughnut" model, der angiver "hullet" imellem de planetære og de sociale grænser for økonomisk aktivitet, og hun har konstrueret en model for målinger, der kan anvendes til en bæredygtig udvikling.

Med fællesressourcer er der skabt grobund for en bevidst og overvåget sammenhæng mellem mennesker og natur, hvilket kan skabe miljø- og klimamæssige gevinster samtidig med, at den markedsøkonomiske blindhed over for konsekvenser af ubegrænset vækst bringes til ophør.

\footnotetext{
${ }^{1}$ IT governance omfatter følgende:

a) Strategisk overensstemmelse mellem forretningsstrategien og it-strategien

b) Værdigenerering

c) Styring af ressourcer

d) Risikostyring, sikkerhed og regelstyring

e) Performance opfølgning.
}

\begin{abstract}
${ }^{2}$ Ostrom's paradigme er et analyseværktøj - "Institutional analysis and development (IAD)" - for konstruktion af en institutionel ramme om en derved styret "common pool resource" (CPR-gode).
\end{abstract}

Rammeværket henviser til 3 niveauer: Det operationelle, de kollektive valg, og de konstitutionelle regler. I tilknytning hertil er der syv grundregler, som skal iagttages i konstruktionen af CPR-goder.
a) Positionsregler - hvilke roller har deltagerne i CPR-godet;
b) Grænseregler - hvem er valgbare, hvordan valgt, hvordan forlader en valgt sin position;
c) Valgregler - definerer handlinger, der kan, kan-ikke eller skal udføres, fokus er på handlinger.
d) Aggregeringsregler - proces til konfliktløsning (non-symmetrisk, symmetrisk, uenighedsregel);
e) Informationsregler - hvilke og hvordan udveksles information mellem medlemmer og andre og arkiveres;
f) Afkast regler - tilregner gevinst og straf til forskellige handlinger og resultater;
g) Rækkevidde (scope) - hvilke resultater kan, skal, skal-ikke påvirkes eller realiseres i en given situation. Fokus er resultater.

Hver af disse regler skal effektueres på de tre niveauer, således at der er klare sammenhænge mellem det operative, de kollektive og de institutionelle forskrifter. Rammeværket kan ses som en drejebog for etablering af en governance for CPR-goder. I stedet for "den usynlige hånd” tager mennesker selv ansvar for deres økonomiske handlinger og disses konsekvenser. 


\section{Referencer}

Al-Debei, Mutaz M. and David Avison (2010). Developing a unified framework of the business model concept. European Journal of Information Systems, 19 (3), 359-376.

https://doi.org/10.1057/ejis.2010.21

Anbefalinger (2010). Selskab for God Selskabsledelse.

Arthur, W. Brian (2009). The Nature of Technology. Free Press NY 2009.

Arthur, W. Brian (2011). The Second Economy. McKinsey Quarterly, October.

Beniger, James R. (1986). The Control Revolution. Ballinger. Cambridge, Mass.

Benkler, Yochai (2006). The Wealth of Networks. Yale U.P.

Benkler, Yochai (2011). The Penguin and The Leviathan: How Corporations Triumphs over SelfInterest. Random House.

Berger, Peter L. \& T. Luchmann (1966). The Social Construction of Reality. N.Y. Doubleday.

Brynjolfsson, Eric \& Andrew McAfee (2014). The Second Machine Age: Work, Progress, and Prosperity in a Time of Brilliant Technologies. Norton \& Company. https://doi.org/10.1177/0268580916655972

Castell, Manuell (1996). The Rise of the Network Society. Oxford: Malden.

Chircu, A.M. \& R.J. Kauffman (2000). Reintermediation strategies in business-to-business electronic commerce. International Journal of Electronic Commerce, 4 (4), Summer 7-42. https://doi.org/10.1080/10864415.2000.11518377

Coase, Ronald H. (1937). The Nature of The Firm. Economica vol. 4, November. 386-405.

Dansk IT (2006). IT Governance anbefalinger. København.

Dansk IT (2011). God IT skik. København.

Dreyfus, H \& Dreyfus, S. (1986). Mind Over Machine. New York: Free Press.

Durkheim, E. (1895). Règles de la méthode sociologique. Paris,

Erhvervsstyrelsen (2019). Cookietyper. https://erhvervsstyrelsen.dk/mod-de-vaesentligstecookietyper

Elster, Jon (1979). Ulysses and the Sirens. Cambridge University Press.

Evans, D.S., A. Hagiu, and R. Schmalensee (2006). Invisible Engines: How Software Platforms Drive Innovation and Transform Industries. Cambridge, MA, US: MIT Press. https://doi.org/10.7551/mitpress/3959.001.0001 
Gawer, A. and M.A. Cusumano (2002). Platform Leadership: How Intel, Microsoft, and Cisco Drive Industry Innovation. Boston, MA, US: Harvard Business School Press. https://doi.org/10.5172/impp.2003.5.1.91

Görsch, Daniel \& M. Kühn Pedersen (2000). E-Channel Competition: A Strategic Approach to Electronic Commerce. November 1999. 8th European Conference on Information Systems, Proceedings, Vol. 2, 1066-1073. July 2000.

Hardin, Garrett James (1968). The Tragedy of the Commons. Science 162, December 3, 1968: 12431248.

Hess, C. and Ostrom, E. (2001). "Artifacts, Facilities, And Content: Information as a Common-pool Resource", Workshop in Political Theory and Policy Analysis. http://www.law.duke.edu/pd/papers/ostromhes.pdf

Jacobson, Daniel, Greg Brail \& Dan Woods (2012). API's: A Strategy Guide. O'Reilly. Sebastopol, CA 95472; Evolved Media, 9781449308926.

Kallinikos, Jannis, Aleksi Aaltonen, Attila Marton (2010) A theory of digital objects. First Monday, vol. 15, 6-7; June 2010. https://doi.org/10.5210/fm.v15i6.3033

Ostrom, Elinor (1990). Governing the Commons. Cambridge U P 1990.

Ostrom, Elinor (1998). The comparative study of public economies. The American Economist, 42 (1) Spring, 3-17.

Ostrom, Elinor (2010). Beyond Markets and States: Polycentric Governance of Complex Economic Systems. American Economic Review 100, June 2010, 641- 672.

https://doi.org/10.1257/aer.100.3.641

Pedersen, Mogens Kühn (1987). Netværk i udvikling. NordReFo. 4, 37-50.

Pedersen, Mogens Kühn (1996). A Theory of Informations. Samfundslitteratur.

Pedersen, Mogens Kühn (2001). e-Aktiver: Værdiforøgelse i den nye økonomi. Økonomistyring og Informatik, Årgang 17, Nr. 2. 137-159.

Pedersen, Mogens Kühn (2015). Strategic compliance - an introduction. Revision \& Regnskabsvaesen, 85 (11) 55-61.

Pedersen, Mogens Kühn (2016-17). Strategisk compliance og regulering. Økonomistyring og Informatik, Årgang 32, Nr. 1, 2016-17. 35-66.

Pedersen, Mogens Kühn (2018). Bitcoins - virtuelle penge. Revision \& Regnskabsvoesen, 87 (5) 58-64.

Pedersen, Mogens Kühn (2019). Blockchains - i fællesdigitale løsninger. Revision \& Regnskabsvasen, 88 (10) 47-54. 
Pedersen, Mogens Kühn \& Michael Holm Larsen (2005). Innocuous Knowledge: Models of Distributed Knowledge Networks. In Desouza, Kevin C. (Ed.) New Frontiers of Knowledge Management. Palgrave Macmillan. Basingstoke, Hampshire.

Pedersen, Rasmus Ulslev \& Mogens Kühn Pedersen (2014). Micro Information Systems : New Fractals in an Evolving IS Landscape. In: Nanotechnology: Concepts, Methodologies, Tools, and Applications. Vol. 1, Hershey, PA : Idea Group Publishing 2014. 533-555. https://doi.org/10.4018/978-1-46665125-8.ch022

Raworth, Kate (2017). The Doughnut Economy. Random House.

Sarbanes-Oxley Act 2002. US Department of Commerce.

Selskab for god Selskabsledelse. Anbefalinger. April 2010.

Turing, Alan (1950). Computing Machinery and Intelligence. Mind, 59 (236): 433-60.

Webb, Eugene J. et al. (1966). Unobtrusive Measures: Nonreactive Research in The Social Sciences. Chicago: Rand McNally.

Weill, Peter \& Ross, Jean W. (2004). IT Governance - How Top Performers Manage IT Decision Rights for Superior Results. Harvard Business School Press. Boston. Massachusetts.

Williamson, Oliver (1975). Markets and Hierarchies. Free Press.

Williamson, Oliver (1979). Transaction-Cost Economics: The Governance of Contractual Relation. $J$. Of Law and Economics, vol.22, 2, October, 233-261. https://doi.org/10.1086/466942

Zuboff, Shoshana (1988). In the Age of the Smart Machine. The Future of Work and Power. N.Y. Basic Books.

Zuboff, Shoshana (2015). Big other: Surveillance Capitalism and the Prospects of an Information Civilization. Journal of Information Technology, March, 30(1) 75-89. https://doi.org/10.1057/jit.2015.5

Zuboff, Shoshana (2019). Overvågningskapitalismens tidsalder. Informations Forlag. 